\title{
'Sterling' Dieffenbachia
}

\section{R. J. Henny, ${ }^{1}$ J. Chen, and D.J. Norman \\ University of Florida, Institute of Food and Agricultural Sciences, Mid- Florida Research and Education Center, 2725 Binion Road, Apopka, FL 32703}

Additional index words. foliage plant, foliage plant production, plant breeding

\begin{abstract}
Species and cultivars of Dieffenbachia Schott. (Araceae Juss.) have been important ornamental foliage plants for many decades. Their attractive foliar variegation, adaptability to interior environments, and ease of production are major reasons for their importance as ornamental foliage plants. Approximately 20 cultivars are commercially produced in Florida. Previously, most new cultivars were clones introduced from the wild or chance mutations of existing cultivars. Currently, cultivars are introduced into production from plant breeding programs (Henny 1995a, b; Henny and Chen, 2003; Henny et al., 1987). The hybrid Dieffenbachia 'Sterling' was developed by the tropical foliage plant breeding program at the Mid-Florida Research and Education Center.
\end{abstract}

\section{Origin and Description}

Dieffenbachia 'Sterling' was selected from the progeny of a cross of Dieffenbachia 'Victory' (Henny et al., 1987) and Dieffenbachia 'Tropic Marianne' (U.S. Plant Patent No. 8832). The 'Sterling' pedigree involves two unknown species and six named cultivars (Fig. 1). Both parent plants are heterozygous for the presence of foliar variegation. 'Victory' (female parent) has variegated leaves $(P v p v)$ consisting of many irregular islands and spots of yellow (RHS 154D; Royal Horticultural Society, 1995) and cream (RHS 154C) against a green (RHS 137A) background with a narrow solid green (RHS 137A) margin. 'Tropic Marianne' (male parent) has golden yellow (RHS 150C) leaves $\left(P v^{l} p v\right)$ with a narrow green (RHS 137A) margin (Henny, 1982). 'Sterling' is homozygous recessive $(p v p v)$ for foliar variegation and therefore has uniform green leaves (Henny, 1982). The seedling was selected from 104 progeny obtained from the aforementioned cross. 'Sterling' was selected because of its vigor, good plant form, and showy dark green leaves that were further highlighted by a bright white midrib (Fig. 2). The leaf color pattern is uniform dark green with mature leaf blades being green (RHS 137A) (Royal Horticultural Society, 1995) on the adaxial surface and green (RHS 137D) on the abaxial surface. Newly opened leaves are lighter green (RHS 137B) than older leaves, but turn a darker green (RHS 137A) a few days after expansion. The leaf midrib is thick and prominent with a width of $1 \mathrm{~cm}$ at the base of the leaf to approximately 0.7 to 0.8 $\mathrm{cm}$ at a distance equally between the leaf base and the leaf tip. The adaxial and abaxial leaf midrib color is white (RHS 155D). Leaf length averages 2.3 times the width, and mature leaves may reach a length of $36 \mathrm{~cm}$ and a width of $15.5 \mathrm{~cm}$.

Received for publication 7 Feb. 2006. Accepted for publication 7 Apr. 2006.

${ }^{1}$ To whom correspondence should be addressed; e-mail rjhenny@ifas.ufl.edu.

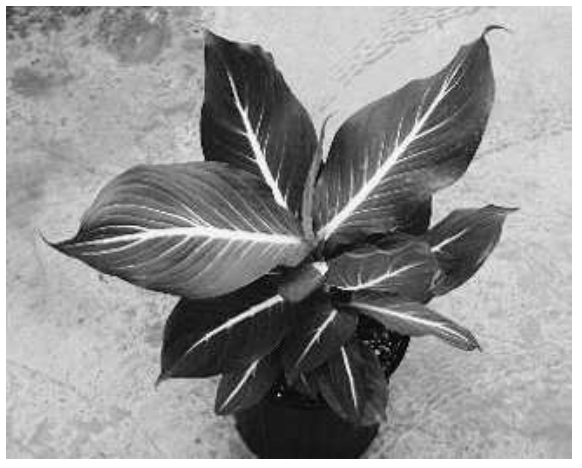

Fig. 2. A mature plant of Dieffenbachia 'Sterling' in a $3.9-\mathrm{L}$ pot.

leaves averaged $36 \mathrm{~cm}$ in length and $15 \mathrm{~cm}$ in width. Plants averaged better than 6 basal shoots per plant, eliminating the need for multiple plants grown per pot to achieve a full look. Plant quality was good to excellent overall with slightly higher ratings for plants at the higher nutritional levels.

\section{Availability} Liners were potted into $1.6-\mathrm{L}$ plastic pots containing a substrate of Vergro Container Mix A (Verlite Co., Tampa, Fla.). Plants were grown in a shaded greenhouse with a maximum irradiance of $125 \mu \mathrm{mols} / \mathrm{m}^{-2}$, natural photoperiod, and a temperature range of 15 to $34{ }^{\circ} \mathrm{C}$. Plants were grown for 20 weeks ( 28 Mar. 2000 until 15 Aug. 2000). Ten plants were grown at each of 3 fertilizer levels equivalent to $8.4,11.2$, and $14.0 \mathrm{~g} / \mathrm{N} / \mathrm{m}^{-2}$ per month $^{-1}$. Fertilizer levels were derived from a 3:1:2 ratio of $\mathrm{N}: \mathrm{P}: \mathrm{K}$ applied as a liquid drench at $100 \mathrm{~mL}$ per pot weekly. The treatments were completely randomized. Data recorded at termination of the study included canopy height and width, length and width of largest leaf, number of basal shoots, and a rating for visual quality in which $1=$ dead, 3 = acceptable (i.e., saleable), and $5=$ excellent quality. Data were analyzed using analysis of variance procedures of SAS (SAS Institute Inc., Cary, N.C.).

Dieffenbachia 'Sterling' reached marketable size in 1.6-L containers within 20 weeks. Fertilizer level did not significantly affect any of the variables measured. In mature plants, average canopy width $(56 \mathrm{~cm})$ was approximately 1.4 times canopy height $(40 \mathrm{~cm})$ and

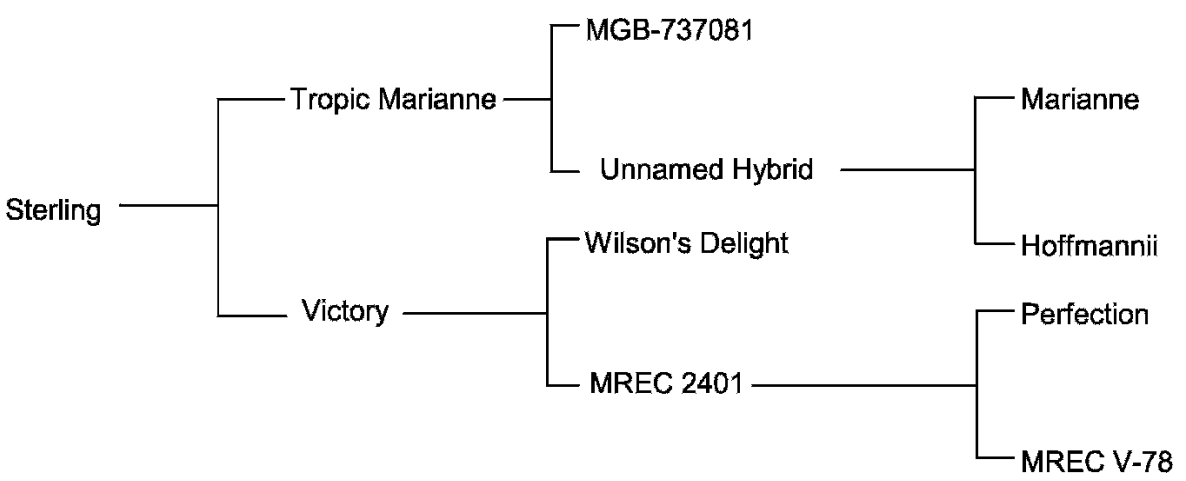

Fig. 1. Pedigree of 'Sterling' Dieffenbachia. 